\title{
Karolina Świrska-Czałbowska
}

Cardinal Stefan Wyszyński University

\section{The image of Poland and Poles in European public discourse: An analysis of polls and articles from the Western press, 2004-2017 \\ Obraz Polski i Polaków w europejskim dyskursie publicznym. Analiza wyników badań opinii publicznej i artykułówz prasy zachodniej w latach 2004-2017}

\begin{abstract}
The concept of this paper is to present how Poland and the Polish people were perceived in the "old" EU countries prior

to the Polish accession to European Union and how the Polish people were evaluated in the context of the "eastern enlargement." The article is an attempt to answer whether the image of Poland has changed due to the inclusion of Poland in the European institutions, and to what extent, as well as how the 13 years

in the EU structures have influenced the perception of our country, amongst both the EU political elites and ordinary citizens. The sources used include public opinion polls, both Polish and international, as well as articles, mainly from the English-language press.
\end{abstract}

KEYWORDS:

European integration, Polish image, cultural stereotypes, dynamics of change

\begin{abstract}
ABSTRAKT
Celem artykułu jest pokazanie wizerunku Polski i Polaków w krajach „starej Unii” oraz zanalizowanie jak Polacy byli oceniani przed akcesją do Unii Europejskiej w 2004 roku i jak są postrzegani obecnie. Niniejsze studium próbuje pokazać, czy w wyniku włączenia polski do struktur europejskich wizerunek naszego kraju się zmienił i na ile; jak nasza ponad 13 letnia obecność w strukturach unijnych wpływa na postrzeganie naszego kraju zarówno wśród elit politycznych państw unijnych, jak i zwykłych obywateli. Wykorzystane są badania opinii publicznej, polskie i międzynarodowe, jak również artykuły prasowe, głównie z prasy anglojęzycznej.
\end{abstract}

\section{SŁOWA KLUCZOWE:}

integracja europejska, wizerunek Polski, stereotypy kulturowe, dynamika zmian 


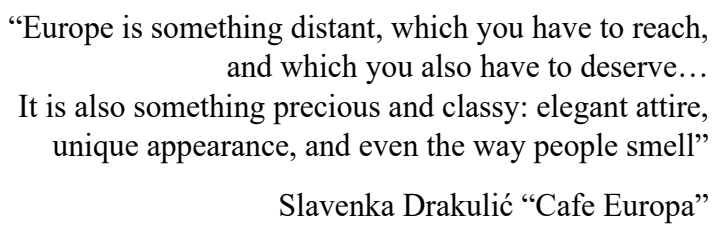

$\mathrm{P}_{\mathrm{o}}$ oland became a member of the European Union in May 2004. It had long been obvious for the societies of the old EU Member States and for their governments that the extension of the EU borders toward the east would pose new challenges. Changes were envisaged for the European Union itself, as it was at the time, and for the rules dictating the Union's functioning, causing a lot of concern among the inhabitants of many Member States. Concern and uncertainty were present on both sides, that is, among the candidate Member States and the old EU-15 Member States. Therefore, it is reasonable to try to present the image of Poland and the Polish people in the "old EU" Member States against the background of the "expansion to the east," and to investigate any changes of this image as a consequence of Poland's accession to the European structures.

The earlier expansion projects - the expansion "to the north" in 1973, "to the south" in 1981 and 1986, and to the "neutral states" of 1995 - did not give rise to so much controversy. The countries that joined the strong and rich Union did not differ significantly from the existing Member States in terms of affluence and civilization advancement (the differences were not particularly significant during the expansions "to the north" and the "southern states"). At the time of the "expansion toward the east" of 2004, however, the situation was different: the new EU member states had only entered the Western path of development less than twenty years before, and they still failed to match the EU member states in terms of the condition of their economy, their political maturity, or their political traditions.

The candidate states' evaluation criteria were also subject to a lot of changes and verifications. As Lena Kolarska-Bobińska wrote on the eve of the integration: "politics and 'soft', non-legal candidate assessment criteria are starting to play a more and more important role in the integration process, not defined or verified, typically based on the stereotypes of countries and societies, as well as the traditions of the historical relations among the states. Hence, it becomes essential to define the image of Poland and the Polish people currently prevailing in the EU Member States, as it promotes the right information and lobbying policies and 
because integration primarily implies a close cooperation among the populations, regions, organizations. ... One way to advance our country's position is to change the perception of Poland. This is because the perception of reality is as important as 'hard' facts, ratios, and numbers."1,2

Wally Olins, a British expert in nation branding, head of Saffron Brand Consultants, a consultancy that was working together with Instytut Marki Polskiej [the Polish Brand Institute] on rebranding Poland, claimed that a good corporate brand is an asset and a value that translates into net profits. Moreover, a wellconceived and perfected image of a state plays a key role in economic and political international relations. Without such an image, gaining foreign investors' confidence and making a presence on the international stage is challenging. Olins presented the following main claims:

1. In the contemporary world, there are three essential fields of economic competition among countries: acquisition of foreign investments; tourism; and export of goods and services.

2. A vast majority of countries and regions that have succeeded in attracting foreign investment were following carefully conceived promotion strategies and creating their image in a structured way (e.g., Wales or Ireland).

3. National stereotypes can significantly affect an individual countries' growth perspectives. Building a "positive stereotype" can make a product's origin an advantage in pursuing sales markets (Brazil).

4. In tourism, there is a huge pricing competition. An attractive geographic location or beautiful nature are no longer sufficient, and nowadays countries attempting to attract tourists have to distinguish themselves from others. Using the same techniques as those applied by suppliers of consumer goods, they have to show what makes them unique (Portugal).

5. States compete with each other using advanced marketing tools. Commercial success depends on whether the images concerning foreign investment, export, and tourism are coherent and mutually supportive - hence the importance of planning, coordination, and systematic management of the national brand (examples of comprehensive branding policies are Spain and the United Kingdom). ${ }^{3}$

Unfortunately, at the time of its accession to the EU, Poland did not enjoy a positive image of itself among its neighbors or more distant Western European states. This issue did not only affect Poland. Even though the countries of the

\footnotetext{
${ }^{1}$ Kolarska-Bobińska 10.

${ }^{2}$ Olins 133-164.

${ }^{3}$ Ibidem.
} 
former Eastern bloc began to support democratic ideas after the fall of communism, their status became different than that of Western European countries, due to the inferior condition of their economies. Even in the official EU nomenclature, the Central and Eastern European countries were labelled as "the other Europe". This, in turn, translated into attitudes, summing up the policy of Western Europe toward the candidate states. Andras Koves noted that

a common issue that the Central and Eastern European countries share is the need to coexist and to function in an atmosphere which they perceive as relatively condescending. All the predictions and outlines made them feel that they were not as important for the rest of the world (which, in their view, meant the Western World) as they could wish."

\section{THE IMAGE OF CENTRAL AND EASTERN EUROPEAN COUNTRIES IN THE OLD EUROPEAN UNION (EU-15) MEMBER STATES AT THE TIME OF THE EU ACCESSION}

Central and Eastern Europe heritage was identified with a heritage of conflict and resentment (e.g., the German issue), a lack of political traditions (such as pluralism or debate), economic underdevelopment (a lack of entrepreneurship and imitative instead of endogenous growth). The differences in political culture (a lack of stability, frequent government changes, and conflicts between politicians and the population) had a strongly negative impact on the perceptions of the Eastern European countries. Because of these characteristics, the Western elites were skeptical about the political elites of Eastern Europe after 1989. The status quo would be compared to the first years after the war in Germany and Italy, facing a shortage of public order and harmony, when the people - tired after the war tended to sympathize with anti-democratic forces.

The essential differences and deficiencies for which the Central and Eastern European countries were reproached can be divided into three categories: political/social; economic; and infrastructural. Among the political/social issues were recognized a different political culture; a lack of stability of the political map, wariness of the political elites as successors of post-communism making them unreliable partners for discussion; and unpredictability of public opinion. Another

\footnotetext{
${ }^{4}$ Koves.
} 
allegation was Poland's old-fashioned social and vocational structure, originating from the domination of an administrative command economy, which was incompatible with the requirements of a capitalist economy and the free market. It was claimed that too many people were working in the farming and industry sectors, with a weaker role of the services sector and modern professions (business, banking, insurance, real estate, etc.). Obsolete, relatively unproductive farming in Poland allegedly needed not only a lot of investment from the EU but also funding from Poland itself. There were also mentions of extensive bureaucratic state systems, low wages, low purchasing power in the population, and passive attitudes toward employment. ${ }^{5}$ The requirements imposed by the European market were expected to modernize the types and proportions of jobs in the Polish society, leading to further social costs.

The following aspects were recognized as economic differences: an old-fashioned economic structure; industrial production estimated to be $30 \%-50 \%$ below the standards required by EU-15 Member States; excessive use of materials and energy; returns from production at significantly lower rates than those generated in the West; and unstable financial markets. There were mentions of shortages of modern infrastructure: an inadequate road network, underdevelopment of inland transportation and air transport, substandard condition of the telecommunication networks, and disregard for environmental protection rules.

Other barriers were the law not matching the principles of the market economy and the level of foreign debt, determined at USD 99.2 billion in 1989 for the Central and Eastern European countries (Poland's debt was estimated at USD 40.4 billion and USD 1,078 per capita; Hungary's was USD 19.7 billion and USD 1,873 per capita; and Czechoslovakia's was USD 6.9 billion and USD 431 per capita). ${ }^{6}$ Moreover, there were concerns about the EU quality standards being an entrance barrier for Polish businesses, preventing them from entering the European markets, as they would not be able to meet those standards without prior modernization efforts and investment. Further important issues included the economy in the border regions, particularly in the eastern part of the country which, through the isolation and tightening of the border, was expected to be deprived of regular sources of income. Curbing the grey zone of border region trading turned out to

${ }^{5}$ For a broader discussion on that topic, see Wnuk-Lipiński.

${ }^{6}$ Płonka 59. 
be a blow to the economic interests of the eastern territory of Poland, causing resistance among the affected part of the population against further changes.

All these issues delayed the negotiation process and the admission of the Central and Eastern European countries to the European Union. It was alluded to them that the consent to their EU membership would depend on their preparedness and compliance with the EU's political and economic requirements.

So, which factors supported the admission of these countries as new EU members? There were mentions of a higher level of safety in Europe, as a result of discontinuation of the cooperation with Central and Eastern European countries. There were concerns about an outbreak of conflict and unrest in that part of Europe, along with the assumption that the Western governments would have to intervene. Closer relations were also supported by the prospects of gaining tens of millions of new consumers as a market for Western European products, as well as a cheaper workforce for Europe's industry. The advantages derived from the increased trading volume and the economic growth in the Eastern countries were expected to be conspicuous all across Europe, not just in the new Member States. There was also a certain relevance to the cultural and historical associations of the Central and Eastern European countries, which spoke in favor of them joining the EU. The prevailing opinion was that the Union composed of 25 members would increase its political potential in the international arena even more.

\section{“WELCOME TO THE EU IF YOU HAVE TO,” OR THE ATTITUDES OF THE PEOPLE OF THE OLD MEMBER STATES TOWARD THE EXTENSION}

Because the acceptance of the integration process in the Member States was one of the objectives set for the EU's communication policy, the people of the old and new EU Member States were regularly polled to determine their attitudes toward the integration process. As described by Prof. J. Holzer, "the starting point for any analysis of mutual perceptions should be an extensive asymmetry. Western Europe's culture, political, and civilization transformations have always been watched and studied here with a lot of interest. However, the Polish culture and the ongoing changes that are taking place in Poland and in the other Visegrád countries were marginalized within the area of the Western interests, more like an exotic item than equal neighborhood."

\footnotetext{
${ }^{7}$ Holzer.
} 
The people of the old EU Member States perceived the Eastern European countries' accession in a completely different way than the people of the new aspiring members.

Table 1. The issues related to the enlargement of the European Union

\begin{tabular}{|l|c|c|c|}
\hline \multicolumn{1}{|c|}{ Claim } & Agree & Disagree & Undecided \\
\hline $\begin{array}{l}\text { The more member states belong to the EU, the higher the Union's } \\
\text { global importance will be }\end{array}$ & $67 \%$ & $17 \%$ & $16 \%$ \\
\hline With more EU members, Europe will become culturally richer & $61 \%$ & $31 \%$ & $8 \%$ \\
\hline $\begin{array}{l}\text { More Member States mean a stronger guarantee of peace and } \\
\text { safety in Europe }\end{array}$ & $59 \%$ & $25 \%$ & $16 \%$ \\
\hline $\begin{array}{l}\text { Before the admission of new Member States, the EU must reform } \\
\text { its institutions }\end{array}$ & $59 \%$ & $16 \%$ & $25 \%$ \\
\hline $\begin{array}{l}\text { Extending the EU with new members means lower funding aid for } \\
\text { my country }\end{array}$ & $47 \%$ & $26 \%$ & $27 \%$ \\
\hline $\begin{array}{l}\text { The more member states belong to the EU, the higher the unem- } \\
\text { ployment rate in my country }\end{array}$ & $35 \%$ & $41 \%$ & $24 \%$ \\
\hline $\begin{array}{l}\text { EU enlargement with new Member States means less importance } \\
\text { of my country in Europe }\end{array}$ & $34 \%$ & $47 \%$ & $19 \%$ \\
\hline $\begin{array}{l}\text { EU enlargement does not imply higher costs for the existing Mem- } \\
\text { ber States }\end{array}$ & $28 \%$ & $49 \%$ & $23 \%$ \\
\hline
\end{tabular}

Source: Eurostat Yearbook 2001: The Statistical Guide to Europe, Data 1989-1999.

The poll showed that $51 \%$ of people in Austria, $47 \%$ of Germans, and $46 \%$ of Greeks agreed with the claim that "the more member states belong to the EU, the higher the unemployment rate", while $62 \%$ of Dutch, $60 \%$ of German, and $58 \%$ of Austrian people answered "yes" to the question about the costs of the EU extension for their respective mother countries. The citizens of Ireland (68\%), Denmark (62\%), Greece, and Finland (61\% each) were concerned about reduced financial aid as a consequence of the extension, yet the percentages of the population approving of the new member states' accession were highest in Denmark, Greece, the Netherlands, Finland, and Sweden. The levels of approval found for Belgium, France, and Luxembourg were much lower.

\footnotetext{
${ }^{8}$ www.eurostat.com.
} 
Moreover, definitive sympathy or antipathy toward individual candidates could be observed. The Greek people were strong supporters of the accession of Cyprus to the EU (88\% support), whereas such nations as Austria and Germany were reluctant to welcome Romania to the Union (14\% support in Austria and $17 \%$ in Germany). Equally pronounced was the decrease of support for the admission of such countries as Poland and Hungary. ${ }^{9}$

The old EU members' societies were happiest to see Norway and Switzerland in the Community, as they were rich countries at a high level of civilization advancement which would not need funding. Subsequent community polls proved that the trend of decreasing sympathy toward the eastern expansion was maintained. The levels of support for the enlargement among the societies of the old EU 15 Member States, according to the Eurobarometer study no. 59, from spring 2003 are presented in Table 2.

Table 2. EU Member States vs. the Eastern enlargement

\begin{tabular}{|l|c|c|c|}
\hline \multicolumn{1}{|c|}{ Member State } & For (\%) & Against (\%) & Undecided (\%) \\
\hline Sweden & 56 & 34 & 10 \\
\hline Finland & 50 & 40 & 10 \\
\hline Netherlands & 48 & 38 & 14 \\
\hline Italy & 60 & 19 & 21 \\
\hline United Kingdom & 36 & 36 & 28 \\
\hline Denmark & 63 & 25 & 12 \\
\hline Belgium & 38 & 44 & 18 \\
\hline Luxembourg & 53 & 40 & 19 \\
\hline Germany & 42 & 39 & 13 \\
\hline Austria & 43 & 44 & 15 \\
\hline France & 31 & 54 & 23 \\
\hline Spain & 60 & 17 & 18 \\
\hline Portugal & 60 & 22 & 19 \\
\hline Italy & 59 & 22 & 10 \\
\hline Greece & 71 & 19 & \\
\hline
\end{tabular}

Source: Eurobarometer no. 59, spring 2003

${ }^{9}$ Walkiewicz 57; for a broader discussion of that topic, see also European Commission. 
There was a prominent decrease of the number of supporters of the EU expansion to the east. In Belgium, the number of people against uniting the continent exceeded the number of supporters. A similar situation occurred in France and Austria. There were also major decreases of endorsement in Finland, the Netherlands, and Germany. In France, with its traditionally strong anti-American sentiments, Jacques Chirac commented on Poland's involvement in a war that was highly unpopular in Europe by "accusing them (the Eastern European countries) of acting irresponsibly by expressing their opinions. ${ }^{10}$ Time after time, comments would appear in the press to describe the Member States' increasing reluctance toward the admission of new members: "Welcome to the EU if you have to,"11 "Rough accession,"12 "Economic apartheid,"13 or "No illusions."14

In 2001, there was a lot of publicity about a qualitative survey report drafted by OPTE, a French research agency hired by the European Commission, entitled "The image of the European Union, the social attitudes and expectations in the 15 member states and the 10 candidate countries." The study was organized in coordination with local research agencies, with the objective of determining the mutual perceptions of the citizens of the old EU member states and the candidate countries. The Polish part of the study was conducted by BSM Social and Marketing Study Agency, and the results were presented, on the Polish Press Agency site, among others. ${ }^{15}$

The report presents Poles in a way that can be considered insulting. Here is a set of quotations from this extensive 200-page compilation:

The Poles are concerned about forever remaining poor, unfamiliar, and disrespected relatives (p. 12). The concerns surpass the hopes which, for reasons of extraordinary pessimism, they are unable to express (p. 17).

Polish people consider themselves to be the poor, without proper access to the society of the wealthy. Their poor language competencies limit their communication ability. As a matter of fact, they are characterized by an inferiority complex, linked to the negative perception of the Poles abroad, where they are seen as fraudsters

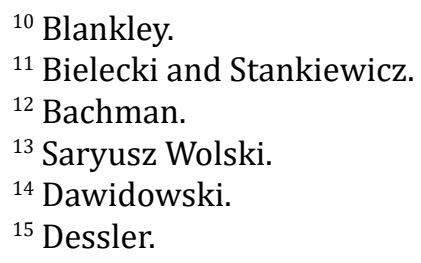


and thieves ... Added to this is the vivid national sentiment, which can finally be fully expressed after years of foreign occupation and partitions. Their feeling of dignity is primarily defensive (p. 47).

The image of the Community which prevails among us is that of an economic union of rich countries. The goals at its foundation are neither very popular nor appreciated. The Poles have a tendency to bring everything down to economic categories (p. 80). ${ }^{16}$

Further research of the images of countries and nations was carried out by Instytut Spraw Publicznych [the Public Affairs Institute] in 2003. It covered almost all the Western European states (Austria, Spain, Sweden, France, the United Kingdom, and Germany). The results of these studies also demonstrated that Poland or other Central and Eastern European countries were not treated as equal partners in the negotiation process. Most respondents did not have any opinion about Poland at the time; ignorance prevailed with regard to all the strategic growth areas of Poland. Only 15\% of the people in Germany, Austria, and Spain and 18\% of those in France were aware that there was a market economy functioning in Poland, whereas only 30\% of Germans and Austrians and 25\% of French people believed there was democracy in Poland. One third (32\%) of the respondents in Germany and Austria declared that our parliamentary system was similar to the one prevailing in Western Europe. ${ }^{17}$ The image of Poland as a candidate country was completely different than that of the EU member states:

The Central and Eastern European countries were perceived within the Union as distant in terms of geography and civilization, economically and politically different from the old member states. Poland was seen as dissimilar to the respondent's respective country: Catholic, traditional, backward, strongly corrupt, with a poor work organization and an economy not matching the economies of the European Union member states. ... In the eyes of the West, Poland has liberated itself from communism, but has not yet managed to overcome the political and economic consequences of that political system. However, the Western societies are unaware of the position Poland is in right now, how far it has gone away from communism, or when it will begin to resemble the European Union states. ${ }^{18}$

16 "UE- Polak to pazerny fatalista; for a broader discussion of the subject, see Skotnicka-Illasiewicz.

${ }^{17}$ Kolarska-Bobińska 9-16.

${ }^{18}$ Ibidem. 
In terms of research, it appears to be equally interesting to investigate how the EU negotiators perceived their Polish counterparts in the accession process:

It was obvious for the Commission officials that the candidate states were more interested in joining the Union and quickly negotiating the agreement. The eastern enlargement countries, even compared to the southern enlargement states, were perceived as countries with no other alternative. ... It was a source of controversy when confronted with the pressing attitudes of the candidate countries' representatives: "They have very high aspirations, but very poor arguments on their side." ... In the case of Poland, there was the unique belief of the "non-compatibility of its interests with those of the EU." Spain used to be perceived in a similar way. ... For a comparison, Scandinavian countries were considered perfectly prepared, with a professional administration, "rich, well known, close friends." However, the eastern enlargement candidates were seen as poor, distant relatives, "second class passengers." ${ }^{19}$

Thus, at the time of the EU expansion, the elites and the peoples of Western Europe perceived us as a backward, economically underdeveloped country. For most of them, Poland was terra incognita, and no special chance was on the horizon for changing the situation. Paradoxically, even the famous Poles, attracting national pride in Poland, such as Chopin, Maria Skłodowska-Curie, or Copernicus, were not always identified with Poland. The former two are still perceived as French, and the latter as German. ${ }^{20}$ A certain ambiguity was noticeable in Poland's status during the negotiation process: namely, Poland was considered one of the most important new member states, due to its size, population, geography, and economic growth rate. On the other hand, however, we were often reproached for "Poland being a candidate that balanced on the border of falling off the first wave of enlargement, being poorly prepared for integration (in comparison with Hungary and Slovenia, for example), with a lot of deficiency in the process of adopting acquis communautaire. ... There were some strongly emphasized suggestions to the effect that Poland's attitude was harmful not just for the country itself, but to other candidates as well." ${ }^{21}$ When the Iraq war started, the list of national flaws was extended with the "double loyalty" we showed toward the Western European countries' governments. There were voices about Poland's "blind pro-American-

\footnotetext{
${ }^{19}$ Commission officials interviewed for Victor Martinez Reyes (213-214).

${ }^{20}$ Grzeszak.

${ }^{21}$ Warchala.
} 
ism" and the Polish "Trojan horse." Had the decision about EU accession been determined by referenda or the support of member states' societies, our accession to the Community would have been very improbable.

\section{THE IMAGE OF POLAND AND POLES IN THE OLD EU MEMBER STATES DURING THE POST-ACCESSION PERIOD: POLAND'S INITIAL SUCCESSES}

Today, more than a decade after our country's accession to the European structures, the same question needs to be asked: How is Poland perceived today? Has its image changed significantly, has it improved and if so, to what extent?

Firstly, it should be noted that Poland's and the Visegrád countries' accession to the EU structures automatically translates to an improvement of their image, as it means a "formal recognition by other Member States that Poland has fulfilled the Copenhagen criteria, meaning that it is a state built on the basis of the rule of law, respect for the rights of minorities, and the market economy."22

Even though it is not common knowledge among the Polish or international public, Poland is climbing up the top economy lists and strongest country brand lists. According to the Country Brand Index report by the agency Futurebrand, Poland moved up the list by three positions in 2011, then ranking 79th out of 113 countries. Yet just a year later, in August 2012, according to Brand Finance agency, which estimates national brand values worldwide, "Poland's national brand recorded the largest spectacular growth of value and, for the first time in the history of the classification, found itself among the top 20 most valuable brands worldwide." ${ }^{23}$ Poland moved up from 24th to 20 th, and the value of the Poland brand was determined at USD 472 billion for the first time. Of all the surveyed nations and their brands, the value of Poland's brand experienced the highest rate of increase, at $75 \%$. According to the authors of the survey, Poland achieved these rates due to its anticipated $3 \%$ growth in GDP, which is considered a particularly rapid growth rate.

Another success was recorded by Poland in the latest World Bank "Doing Business 2017" classification. Out of the 190 surveyed countries, our position was 24th, one number higher than in 2016. The main reasons behind this

\footnotetext{
${ }^{22}$ Fomina and Frelak 11.

${ }^{23}$ Niklewicz 261-262.
} 
advancement were the reforms of the tax law, restructuring, and bankruptcy law, which contributed to a significant improvement of the status of business owners in Poland. We are now ahead of most countries in our region: the Czech Republic ranked 27th, Slovakia 33rd, Romania 36th, Bulgaria 39th, and Hungary 41st. Only the Baltic states ranked higher than us: Estonia moved up from 12th to 10th, Latvia ranked 14th, and Lithuania ranked 21st. ${ }^{24}$

The Polish society is considered one of the youngest on the continent, which - in view of the demographic crisis among the aging populations of Western Europe and the problems they are facing as a consequence of generational imbalance, low performance of the pension system, and the need to import a workforce in the future - presents Poland as a country of new opportunities.

Poland is more and more often perceived as a country of new opportunities, with economic growth rates reaching above 3\% GDP per year. At the time of accession to the European Union, the nominal GDP value in Poland was at PLN 883.7 billion; 10 years later, this value was already at PLN 1,635.7 billion, which was almost twice as much. GDP per capita in 2004 was at $50.5 \%$ of the EU average; 10 years later, it exceeded $66.8 \%$ of the EU average. If a similar economic growth rate is maintained, GDP per capita in Poland is expected to reach $70 \%$ of the average in the old EU-15 member states by $2025 .^{25}$

The value of foreign investment in Poland is steadily increasing, evidence of more confidence from Western business owners in our country. With the EU subsidies, Polish towns and cities are developing as well. The Polish society is

${ }^{24}$ http://www.doingbusiness.org/reports/global-reports/doing-business-2017

${ }^{25}$ http://www.bankier.pl/wiadomosc/PKB-na-osobe-w-Polsce-goni-srednia-UE-Mocnywzrost-do-2018-roku-7255686.html 
considered one of the youngest on the continent, which - in view of the demographic crisis among the aging populations of Western Europe and the problems they are facing as a consequence of generational imbalance, low performance of the pension system, and the need to import a workforce in the future - presents Poland as a country of new opportunities.

Polish business operators are also gaining confidence in winning foreign markets. Here, KGHM Polska Miedź SA is the leader among Polish companies, and the "made in Poland" identification is receiving better and better associations in consecutive countries. Specifically, buses with the Polish brand Solaris travel the roads of Norway, Germany, Austria, and Italy. Pesa, in Bydgoszcz, manufactures trains that are operated not only in Poland but also in Russia, Czechia, Germany, and Italy. Polish windows from Fakro, Drutex, and Oknoplast find buyers in Ukraine, Hungary, Germany, the United Kingdom, France, the United States, Austria, Switzerland, Australia, and the Middle East. Ursus exports its tractors to African markets, while Inglot has found customers for its cosmetics not only in Western Europe and the United States, but also in the Philippines, India, Arab countries, and South Africa. CD Project had its commercial displayed in Times Square, New York City, and it sold 16 million copies of its game "The Witcher" worldwide. Audioteka, with its proprietary audiobook selling scheme, is gaining popularity worldwide. ${ }^{26}$

The Polish premium brands are also becoming more and more popular. Ninety percent of the yachts from Sunreef, Galeon, and Delphia are exported all over the world. Polish vodkas such as Belvedere and Chopin are considered luxury products. Irena Eris is present in Germany and the United Kingdom (its products are available from Harrods, London); in France, it has made its presence in the prestigious Comite Colbert. Polish hotels and spa travel are starting to score high as well. Polish businesses are marking their presence in the segment of luxury brands.

Last year, Poland ranked among the 20 most frequently visited countries in the world. Since 2000, 220 million tourists have visited Poland, which made Poland the 18th most popular country worldwide and the 11th most popular country for tourists in Europe in 2015. ${ }^{27}$ On November 1, 2015, Lonely Travel experts

${ }^{26} \mathrm{http}: / /$ www.polandgoglobal.pl

${ }^{27}$ http://wyborcza.biz/biznes/1,100896,19329021,polska-w-pierwszej-dwudziestcenajchetniej-odwiedzanych-krajow.html 
recognized our country among the ten worldwide and one of only two in Europe which were awarded the title of "Best in Travel 2016."28 The Lonely Travel experts paid special attention to the following towns in Poland: Wrocław, as the European Capital of Culture 2016; Krakow, as the location of World Youth Day 2016; Łódź; Szczecin; and Gdańsk; among other interesting regions, they included the Masuria lake district and Białowieża forest. As estimated by the Polish Tourist Organization, 16 million tourists came to Poland in 2014, or 1 million more than in 2012. Most of the tourists come to us from Germany, Czechia, Ukraine, and Slovakia, but also from the United Kingdom and the Netherlands. At the moment, earnings from tourism in Poland amount to 5\% of GDP each year.

The election of Donald Tusk as president of the Council of the European Union and Elżbieta Bieńkowska as the European Commissioner for the Internal Market, notwithstanding the comments in Polish, was initially perceived as a success for Poland. Among the international opinions, the prevailing approach was that it did not equate to Poland achieving equal status with that of the remaining EU-15 member states, but rather of an international position which had been completely unavailable for Poland before.

\section{POLAND MORE THAN 10 YEARS AFTER ITS EU ACCESSION: POLISH AND INTERNATIONAL PUBLIC OPINION POLLING}

The opinion polls carried out in Western European countries, however, demonstrate that Poland is still perceived as one of the poorest countries in Europe. Greece is presented in a similar way today. "European perception of life in other countries," 29 a survey conducted in March 2016 by Livewhat, an agency affiliated with the Institute of Citizenship Studies (InCite) at Geneva University, indicated that only $25 \%$ of the respondents from the surveyed countries were of the opinion that the living conditions in Poland were good. Also, most of the respondents claimed that living in Poland (and in Greece) was "worse than the country thinks," while the Polish people had a more positive image of their neighbors. For comparison, Switzerland and Sweden scored highest among all the subjects; Germany

${ }^{28}$ http://www.pot.gov.pl/nowosci/l/wiadomosci/wiadomosci-z-pot/nagrody-best-intravel-2016-rozdane- polska-w-czolowce-swiatowych-destynacji-turystycznych

${ }^{29}$ Livewhat, Geneva-based survey, quoted in "Green-eyed continent". 
ranked high as well. The position of Greece was the lowest in the classification: in most of the surveyed countries, only $10 \%$ of respondents believed that the living conditions are adequate there. The Southern European countries such as Spain and Italy scored slightly better than Poland. Interestingly, most citizens of the surveyed countries (France, Germany, Italy, Sweden, and Switzerland) declared that living in their neighbor's country is better than in their home country (Table 3).

Table 3. Europeans' perceptions of life in other countries

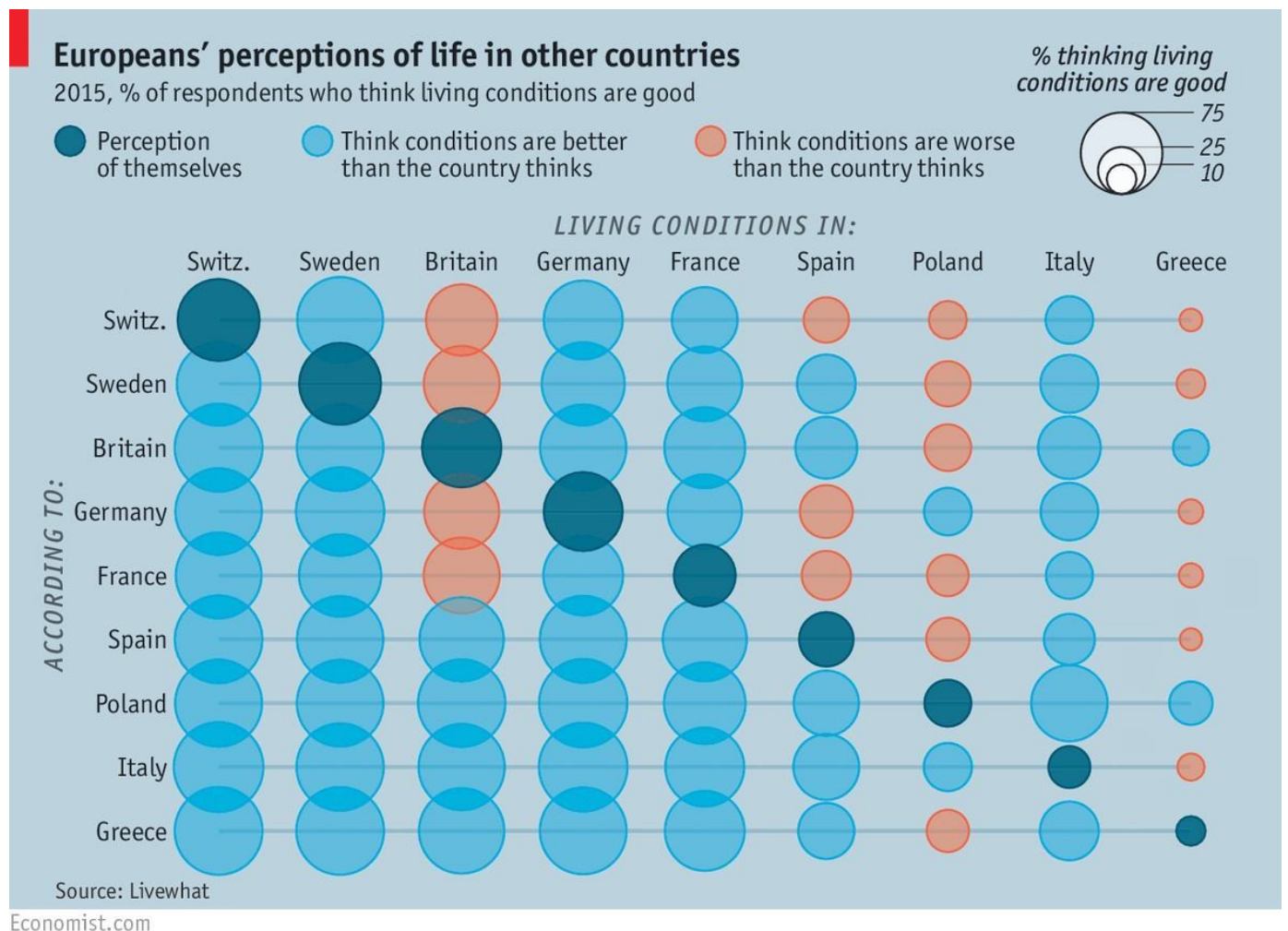

Source: Livewhat, Geneva-based survey, “The Economist”, 29-03-2016

It is symptomatic that the support for further EU enlargement in the old EU15 states is maintained at a low level. The latest Eurobarometer study of November 2016 showed that the support for further expansion of the Union in among founder members was still low: $71 \%$ of the people in Austria, $68 \%$ of those in Germany, and 65\% in France or Luxembourg stood against the process. The EU 
citizens demonstrating a high level of support of the EU enlargement usually were from the recently admitted countries, such as Lithuania (65\% positive responses), Croatia (62\%), or Romania $(61 \%)^{30}$ (Table 4).

Table 4. Support for further enlargement in the European Union member states

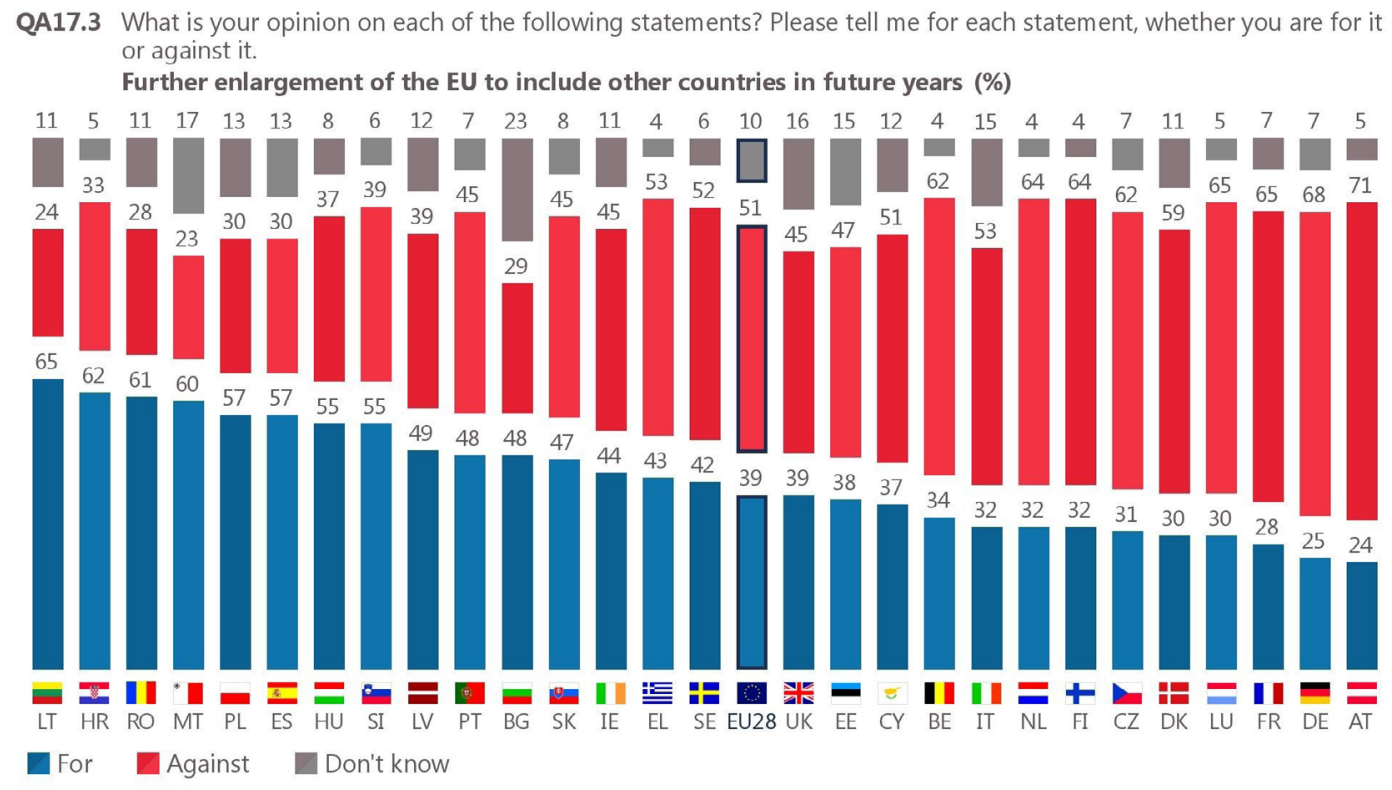

Source: Standard Eurobarometer no. 86, November 2016

The image surveys carried out by Pew Research Center, on the other hand, focused on a more delicate subject, i.e., mutual national stereotypes. ${ }^{31}$ In the 2013 Pew study, Germans were chosen as the "most trustworthy" nation, but the respondents also voted for them as the "most arrogant" and "least compassionate" (responses chosen by the majority of the subjects). In this classification, Poles were described as the "least arrogant" and the "most compassionate" by their compatriots only, whereas the other subjects did not mention Poles in these categories (Table 5).

${ }^{30}$ Standard Eurobarometer 22.

${ }^{31}$ https://richardbrenneman.wordpress.com/2013/05/14/chart-of-the-day-howeuropeans-see-each-other/ 
Table 5. Building stereotypes in Europe

\begin{tabular}{|c|c|c|c|c|c|c|}
\hline \multirow[b]{2}{*}{ Views in: } & \multicolumn{5}{|c|}{$\begin{array}{l}\text { Who Is Trustworthy, Arrogant and Compassionate } \\
\text { EU nation most likely to be named... }\end{array}$} & \multirow[b]{2}{*}{$\begin{array}{l}\text { Least } \\
\text { Compassionate } \\
\text { Germany }\end{array}$} \\
\hline & $\begin{array}{l}\text { Most } \\
\text { Trustworthy } \\
\text { Germany }\end{array}$ & $\begin{array}{l}\text { Least } \\
\text { Trustworthy } \\
\text { France }\end{array}$ & $\begin{array}{l}\text { Most } \\
\text { Arrogant } \\
\text { France }\end{array}$ & $\begin{array}{l}\text { Least } \\
\text { Arrogant } \\
\text { Britain }\end{array}$ & $\begin{array}{c}\text { Most } \\
\text { Compassionate } \\
\text { Britain }\end{array}$ & \\
\hline France & Germany & Greece & France & France & France & Britain \\
\hline Germany & Germany & Greece/Italy & France & Germany & Germany & Britain \\
\hline Italy & Germany & Italy & Germany & Spain & Italy & Germany \\
\hline Spain & Germany & Italy & Germany & Spain & Spain & Germany \\
\hline Greece & Greece & Germany & Germany & Greece & Greece & Germany \\
\hline Poland & Germany & Germany & Germany & Poland & Poland & Germany \\
\hline Czech Rep. & Germany & Greece & Germany & Slovakia & Czech Rep. & Germany \\
\hline
\end{tabular}

Source: Pew Research Center, May 2013

The image of Poland that is presented by the Polish opinion polls and research papers published in Poland irrefutably seems to be more positive than that transpiring from Western reports or statistics. Here, the focus is on the growth rate of positive change, the decreasing distance toward the developed countries, and the progress we have managed to achieve recently; in the articles and papers published in Western countries, the main emphasis is on the reluctance toward further enlargement presented by the Western societies, as well as the threats occurring on the job market as a consequence of the migration waves or the negative perception of the eastern enlargement. 
The Germans were presented as the "most hardworking" and the "least corrupt" in all the comparisons. The opinions on the Greeks were the worst. On top of the disgraceful list of the "least hardworking" and the "most corrupt" nations (Table 6), there are usually the nations of Southern Europe - Italians, Spaniards, and Greeks. ${ }^{32}$ None of the surveyed nations mentioned Poles in their responses, which may be a source of optimism, as the high level of corruption was one of the negative features we were accused of at the time of EU accession.

Table 6. Building stereotypes in Europe

\begin{tabular}{|c|c|c|c|c|}
\hline \multicolumn{5}{|c|}{ Stereotyping in Europe } \\
\hline \multicolumn{5}{|c|}{ Who Works Hardest, Who's Corrupt } \\
\hline Views in: & $\begin{array}{c}\text { Most } \\
\text { Hardworking }\end{array}$ & $\begin{array}{c}\text { Least } \\
\text { Hardworking }\end{array}$ & $\begin{array}{c}\text { Most } \\
\text { Corrupt }\end{array}$ & $\begin{array}{l}\text { Least } \\
\text { Corrupt }\end{array}$ \\
\hline Britain & Germany & Greece & Italy & Germany \\
\hline France & Germany & Italy & Italy & Germany \\
\hline Germany & Germany & Greece & Italy & Germany \\
\hline Spain & Germany & Greece & Spain/Italy & Germany \\
\hline Italy & Germany & Romania & Italy & Germany \\
\hline Greece & Greece & Italy & Greece & Germany \\
\hline Poland & Germany & Greece & Poland & Germany \\
\hline Czech Rep. & Germany & Greece & Czech Rep. & Germany \\
\hline
\end{tabular}

Source: Pew Research Center 2012, "The Economist" 4-06-2012

The reason that no specific mentions of Poland were made in the Pew survey could be that the image of Poland at the time, as the experts pointed out, was as a "country without a face," ${ }^{33}$ without a clear-cut image against the international background. The OBOP survey for the Ministry of Foreign Affairs implied that the image of Poland and Poles in the West was incoherent; on the one hand, the image

${ }^{32}$ Santoso.

${ }^{33}$ Smoczyński; Poland's Marketing Strategy in the tourism sector for 2008-2015; Analysis of Poland's image and Poland's brand worldwide perception survey results 2008. 
of our country was considered unremarkable, while on the other hand it was noted that "the image of the Polish people is better, more prominent than the image of the entire country in a vast majority of cases." ${ }^{34}$

Unfortunately, this does not mean that the image of Poles is identical in all countries; specifically, the TNS OBOP 2013 survey demonstrated that Portuguese, Spanish, French, and Ukrainian people exhibited the most signs of sympathy toward our country. The fewest supporters were in the Netherlands, Austria, and Germany, which is very characteristic because the Netherlands, Germany, and the United Kingdom were the most popular destinations for Polish migrants after 2004..$^{35}$ Another quite obvious conclusion might be that Western Europeans see us as the East of Europe, whereas for the people from the East of Europe, e.g. for the Ukrainian nation, "Poland is already the West." ${ }^{36}$

It would be reasonable to study the results of surveys regarding the image of Poland in selected EU member states. Instytut Spraw Publicznych [the Institute of Public Affairs] carries out regular research projects dedicated to the mutual perceptions of Poles and Germans, called the "Poland-Germany Barometer". ISP's research indicates a certain duality in Germany's perception of Poland. ${ }^{37}$ On the one hand, Poland was even recently associated with a tough economic situation, pushing its people away in order to engage in low-skilled, seasonal jobs; the famous Polnische Wirtschaft was a synonym of extreme mismanagement and a total mess. In some social circles, particularly in the border areas, there was a vivid stereotype of a Pole as a car thief ${ }^{38}$ and an image of Poland as a country with a high crime rate. On the other hand, Poland is more and more often perceived from the

${ }^{34}$ Laboratorium Badań Społecznych for the Ministry of Foreign Affairs 18.

${ }^{35}$ According to the data of the Central Statistical Office of the Republic of Poland (GUS), $2,397,000$ Polish citizens were staying outside of Poland as of the end of 2015, which is the sum of the estimated number of temporary migrants and those who have settled permanently outside of Poland. Specifically, 720,000 Poles were staying in the United Kingdom in 2015 (or more than 1,000,000 according to unofficial data); 655,000 were in Germany; 112,000 were in the Netherlands; and 111,000 had moved to Ireland. The total number of Polish emigrants increased by 82,000 compared to the preceding year.

${ }^{36}$ Laboratorium Badań Społecznych for the Ministry of Foreign Affairs 20.

${ }^{37}$ Instytut Spraw Publicznych.

${ }^{38}$ During the communist times, some sayings were established in everyday speech, such as "Fast gestohlen, schon in Polen" or "Fahren sie nach Polen, ihre Auto ist schon da," meaning "Just stolen, already in Poland" and "Go to Poland, your car is already there", respectively. 
perspective of its rapid economic transformation, numerous investments in infrastructure, and mutual business relations. In 2016, the value of Polish-German trade exceeded $€ 100$ billion ( $€ 22$ billion more than in 2013 ), ${ }^{39}$ making Poland an essential trading partner for Germany. This is also relevant to the nations' mutual perceptions. Specifically, even though Germans had declared they were not of the opinion that Poles as people were similar to them and that they believed we were much closer to Russians, ${ }^{40}$ in later surveys they declared a willingness to accept a Pole as a colleague (79\% positive responses), as a citizen of their country (62\% "yes"), and as a son-in-law (49\%). ${ }^{41}$ This indicates that the level of social acceptance shown by Germans towards Poles exhibits an increasing tendency.

In Belgium, there is also a certain duality in the perception of our country and our people; on the one hand, there is a prevailing stereotypical image of a Pole: a poorly-educated illegal immigrant worker in a low-skilled job, often a heavy drinker. Poland is perceived as a country with a slow growth rate, a cold climate, and a rough history (World War II and the communist years). On the other hand, in the opinion of the international public official population, the image of Poland is completely different, and the qualities attributed to Poles are "ambition, courage, go-getter qualities, youthfulness, and speed", ${ }^{42}$ and the real potential and growth rate of our country is emphasized.

The image of Polish people in the United Kingdom is interesting. During the last 10 years, the perception of Poland has undergone improvement. The British people are mostly aware that Poland is a democratic country, where parliamentary democracy and a market economy prevails. Sixty percent of respondents claimed that they had had some contact with Poland or Poles and consider them trustworthy - they would accept Poles as tourists, neighbors, or family members. Even though only $6 \%$ of Brits had visited Poland, almost half of them believed that Poles are similar to them. However, the perception of Poles in the United Kingdom is not free of all burden; the Brits still consider Poland to be a poor and backward country, affected by corruption and bureaucracy; interestingly, they think

${ }^{39}$ https://www.obserwatorfinansowy.pl/tematyka/makroekonomia/wymianahandlowa-miedzy-polska-a-niemcami-na-rekordowym-poziomie

${ }^{40}$ For a broader discussion on that topic, see Instytut Spraw Publicznych.

${ }^{41}$ For a broader discussion on that topic, see Instytut Spraw Publicznych.

${ }^{42}$ Laboratorium Badań Społecznych for the Ministry of Foreign Affairs 18. 
it is a smaller, less-populated country than it actually is. ${ }^{43}$ In their opinion, Polish immigration has caused an excessive burden to the British social security system and has contributed to higher unemployment rates in certain vocational groups, which may cause certain social clashes. Even though the negotiation process is still pending on the terms of the United Kingdom leaving the EU (the Brexit tensions) and on the limitations on immigrants from the EU using the British welfare system, we may say that there is a certain sympathy toward Poles in the UK. Their jobs are more and more frequently consistent with their profession, meaning that they work as physicians, nurses, engineers, or office assistants - not just as manual laborers. Whatever the level of qualification, their work is appreciated by British employers. "You are Britan's favorite migrants," the British conservative MP Greg Hands allegedly said to Poles. ${ }^{44}$ Similar opinions can be encountered among the Poles residing in the United Kingdom. Dominika Swieżewska wrote that

our hard work, education, and willingness to integrate makes the image of a Pole more and more positive. This is evidenced, for example, by the demand for Polish professionals in the Polish economy. Moreover, there are documents and institutions intended to make it easier for Polish people to integrate and live on the British Isles. Banks offer them loans, Polish women have children, Polish people invest in property and vocational courses. Research shows that Poles still feel more like guests than legitimate inhabitants of the United Kingdom. Yet everything seems to favor the claim that if we continue to work on our positive image, we are going to feel more at home in our migration destinations..$^{45}$

It would be difficult to disregard the fact that migrants are becoming the showpiece of our country abroad and that the changes in the perception of Poland will depend on them. It should be emphasized again that the citizens of our country enjoy more sympathy and a more positive image than the Polish state, which presents itself better and more realistically among the European elites than among the ordinary people.

${ }^{43}$ Ibidem.

${ }^{44}$ M.P. Garapich "Migracje, społeczeństwo obywatelskie i władza. Uwarunkowania stowarzyszeniowości etnicznej i rozwoju społeczeństwa obywatelskiego wśród polskich emigrantów w Wielkiej Brytanii [Migrations, civil society, and power: The criteria of ethnic association and development of civil society among Polish migrants in the United Kingdom], in: Fomina, Frelak, quoted article. p. 14.

${ }^{45}$ Swieżewska. 
The image of Poland that is presented by the Polish opinion polls and research papers published in Poland irrefutably seems to be more positive than that transpiring from Western reports or statistics. Here, the focus is on the growth rate of positive change, the decreasing distance toward the developed countries, and the progress we have managed to achieve recently; ${ }^{46}$ in the articles and papers published in Western countries, the main emphasis is on the reluctance toward further enlargement presented by the Western societies, ${ }^{47}$ as well as the threats occurring on the job market as a consequence of the migration waves or the negative perception of the eastern enlargement. ${ }^{48}$ They also note the deficits and weak points of the new Member States. ${ }^{49}$ Adam Balzer of demosEuropa defined the Poland-EU relationship as "platonic love."50

\section{“POLAND AS EUROPE'S NEW HEADACHE": POLAND AND POLES IN SELECTED MATERIALS FROM THE WESTERN PRESS}

Special attention should be paid to the time period following the October 25, 2015 parliamentary election, when a large volume of articles were published in the Western media that presented Poland in a negative light. Correspondents the foreign press commented on the success of the Law and Justice (PiS) party as an election of "ignorant, xenophobic, even radical Poland." Here are some excerpts from their articles: "Poland has taken a dangerous course towards authoritarianism" [Translator's note: no such quote exists in the reference, so the sentence is my translation of the Polish original and not the English source, see https://www. washingtonpost.com/opinions/polands-disturbing-tilt-to-the-right/2015/11/2 9/480341e0-952a-11e5-8aa0-5d0946560a97_story.html] ${ }^{51}$; "Poland has taken a turn toward Orbán-style authoritarianism" [Translator's note: no such quote exists in Zakaria's GPS transcript at the date given in the reference, so the sentence

${ }^{46}$ Instytut Spraw Publicznych; Laboratorium Badań Społecznych for the Ministry of Foreign Affairs.

${ }^{47}$ E.g., Standard Eurobarometer.

${ }^{48}$ Sedelmeier.

${ }^{49}$ Advisory Council on International Affairs; http://www.cer.eu/sites/default/files/publications/attachments/pdf/2014/bal_comp_ib_eu_enlargement_july2014-9463.pdf.

${ }^{50}$ Balzer.

${ }^{51}$ Diehl. 
is my translation of the Polish original and not the English source ${ }^{52}$; and Poland is bringing back "Soviet-style censorship which ... should be a serious concern for the world" [Translator's note: only a part of this quote exists in the reference; the rest is my translation of the Polish original]..53 The following articles should be noted as well: "Barbed rhetoric"54; "Europe's new headache"55; and "Two weeks in, Poland's new government is making Europe nervous". ${ }^{56}$ Because of the significant emotional component of these texts, they deserve a separate analysis.

Specifically, we can read in the piece entitled "Europe's new headache" that

when PiS was last in power, its tenure was marked by erratic policies and nationalist paranoia; it appears not to have mellowed with time. The last time PiS was in power, in 2005-07, it picked fights with Germany and created an atmosphere of hysterical unpredictability. ... [Poland] has been the flagship of the EU's eastward expansion, proof that democracy and the rule of law can spread. If PiS wants that era to end, it is going about it the right way. ... This lurch towards populism will hurt Poland. But the broader worry is that it will cripple the EU on critical issues, particularly the refugee crisis. ${ }^{57}$

The narrative prevailing in the German media is surprisingly consistent, too. Suddeutsche Zeitung wrote,

the new Polish government under its Spiritus Rector, Jarosław Kaczyński, immediately started to rebuild Poland into a state in which power is no longer divided and controlled, but rather concentrated entirely with Kaczyński and his nationalist PIS party. ${ }^{58}$

Die Welt published the following warning:

The threat that has developed in Poland is no less than a dictatorship, not a communist one this time, but a nationalistic conservative one. This is not only very bad for Poland, but it also mocks the courage and sacrifice of the people who fought and died for democracy in Poland. ${ }^{59}$

\footnotetext{
${ }^{52}$ Zakaria, CNN on Poland.

${ }^{53}$ Zakaria, op. cit.

${ }^{54}$ Foy.

55 "Europe's new headache."

56 "The return of the awkward squad."

57 "Europe's new headache."

${ }^{58}$ Ulrich.

${ }^{59}$ Dietrich.
} 
Frankfurter Allgemeine Zeitung gives the following summary: "The PIS government are doing everything they can to be perceived not as a policy determining force but rather as a problem." 60

The content from Fareed Zakaria of CNN deserves special attention:

Events in Poland have taken a very ugly turn. [Since] the country's right-wing Law and Justice party won the majority in parliament, it has embarked on a dizzyingly rapid power grab that has drawn comparisons with a coup d'etat. In a legally questionable move, the new parliament voided the appointments of five judges to the constitutional court - so they could be replaced with ones to the party's liking... All of this is very troubling and surprising, because in recent years, Poland has been a rare pillow of stability in Europe. Over the last decade its economy grew 50 percent, The New York Times points out, and big companies like Ikea, Volkswagen, and Amazon all have made big investments there. Despite this rosy outlook, the previous ruling party, which had been in power for eight years, had worn out its welcome thanks to scandals and bad politics, so the electorate chose a new course. ... Poland is under threat of "Soviet-style censorship" because freedom of the media is blocked all the time. [Translator's note: this sentence is absent in the original footage of Zakaria and its transcript available on CNN. $]^{61}$

\section{Here is a summary from The New York Times:}

Poland is on its way to a political avalanche, which will take it straight into the arms of brownshirt dictatorship. [Translator's note: this is the translator's version of the sentence written by the author of this paper, yet there is nothing of the kind in the original referenced article from The New York Times. This content simply does not exist in the original text. See https://www.nytimes.com/2016/12/21/opinion/polands-tragic-turn.html. ${ }^{62}$

Fareed Zakaria on CNN again:

If the Republican candidate Donald Trump wins, America could follow in the footsteps of Poland and Russia, where democracy was broken. Democracy is fragile - look at Poland, Russia, and Turkey. [Translator's note: Zakaria never said those exact words, it is rather a compilation of several different pieces from different dates and times]. ${ }^{63}$

\footnotetext{
${ }^{60}$ Veser.

${ }^{61}$ Zakaria, CNN on Poland.

62 "Poland's Tragic Turn."

${ }^{63}$ Zakaria "Global Public Square", CNN on Poland, CNN.
} 
The level of detail in these pieces is interesting, too. Many of them present the political debates in our country on an ongoing basis, as if the authors were perfectly in the current about the sequence of the political events in Poland.

The Economist usually publishes pieces that are not signed with the author's name. In terms of knowledgeability about Poland's internal affairs, this weekly is not in any way behind the largest Polish media outlets. Specifically, in "The return of the awkward squad", we can read the following:

How the new social policies will be funded is unclear. The changes, especially on pensions, are very costly. The proposed taxes on banks and supermarkets cover only a fraction of their cost. The budget deficit could hit 4\% of GDP next year. With an aging population and many young people leaving for elsewhere in the EU, lowering the retirement age seems disastrous. ... European diplomats ... Privately, many are worried. ${ }^{64}$

Here is a quote from "Courting disaster":

Father Rydzyk, too, is disappointed in the new government. After a spat over access to the president, he threatened to break off co-operation, saying he expected his media outlets to be "treated differently". It remains to be seen whom Mr. Kaczynski and his party fear more: the EU or Radio Maryja ${ }^{65}$

The piece entitled "Illiberalism lives" stated the following:

During Ms. Szydlo's attempt to unseat Mr. Tusk, François Hollande, France's outgoing president, snapped that Poland might have the principles, but the EU held the structural funds. You often hear such threats in Brussels and Berlin these days, notably over the refusal of Hungary and Poland to accept refugees. Talks on the EU's next budget begin next year.66

Journalists and experts from Poland echo the content published by foreign correspondents. Piotr Buras said the following in his article, "Driving Poland apart", published in The New York Times: "The real crisis in Poland is not that the country is uniting behind the nationalist right. It is that Polish society is cleaving

\footnotetext{
64 "The return of the awkward squad."

65 "Courting disaster."

66 "Illiberalism lives."
} 
between traditionalism and liberalism." ${ }^{67}$ Professor Jadwiga Staniszkis said in Die Welt that Jarosław Kaczyński "has no empathy towards his own nation." ${ }^{6}$

For a vigilant observer of the daily political scene, the above claims will not be new. A majority of the articles discussed above had their reverberations in the Polish press; they were widely commented upon here. The only surprising aspect can be the early suggestion that the "issues with democracy" are not just the Polish domain under PiS rule, but that Poland "has never been truly democratic before", as a matter of fact. Democratic legitimization was denied for the whole nation. In the January 2017 piece published in Foreign Policy, entitled "Poland was never as democratic as it looked", Sean Hanley and James Dawson suggested that

the political transformation in Poland and in the other countries of the region was not particularly successful, whereas the process of building democracy was stopped halfway. ... The European Union tossed up on the wrong model of democratization for post-communist states. The policies of Brussels have failed because of the assumption that democratization of state institutions will lead to the implementation of democratic values in the society. (...) The superficial democracy is the fault of all the consecutive governments after 1989, and one year is too short to change the entire system of state institutions or the values represented by the society. [Translator's note: this quote, again, never appears in the original article. No idea how the author of this paper obtained the Polish version, or what the real source was. See the original at https://foreignpolicy.com/2017/01/03/ poland-was-never-as-democratic-as-it-looked-law-and-justice-hungary-orban. ${ }^{69}$

Another surprising aspect for a representative of the Polish intelligentsia will be the dichotomy between the allegedly "altruistic west" and the "xenophobic east". In "Barbed rhetoric", Henry Foy and Neil Buckley wrote that

the new members have largely bought into the EU's liberalization agenda ... But today, the rise of nationalism and euroscepticism across central Europe, fueled by the migrant crisis ... is challenging the unity of the European project. ... Now it is the altruistic west against the xenophobic east. Our biggest danger is to fall into this trap. ${ }^{70}$

\footnotetext{
${ }^{67}$ Buras.

${ }^{68}$ Staniszkis.

${ }^{69}$ Hanley and Dawson.

${ }^{70}$ Foy.
} 
The entire Visegrad group is presented in negative terms and characterized by a "lack of European solidarity". PIS's opposition to the election of Donald Tusk for the next term of office as president of the Council of the European Union (it was the first time in history that a member state did not back its own candidate) was commented upon ironically. Here are Henry Foy's comments on Twitter:

Tusk re-elected @eucopresident, Polish Govt fuming (...) It is only just dawning on many EU diplomats just how deep the hatred of Mr Tusk runs within @pisorgpl \& Kaczynski (...) Polish Prime Minister Szydło says Poland will block the conclusions of EU summit on this matter, but she adds that Poland is happy to take the EU money [Translator's note: the last piece is nowhere to be found on Henry Foy's Twitter profile for 2017, so it is my translation and not the English-language original]. ${ }^{71}$

Here it would be reasonable to ask whether any comments could be found during the last eighteen months about Poland and Poles that were positive. Were there any articles (e.g. on any media with a conservative slant) that praised the accomplishments of the new government? There were not many of them, yet it did happen. The World Bank published a report in which it appreciated Poland for implementing the " $500+$ " scheme, through which poverty in Poland was successfully reduced by 3 p.p., from $8.9 \%$ to $5.9 \% .^{72}$

Ruchir Sharma, Global Strategist at Morgan Stanley Investment Management, predicted Poland's economic advancement in 2017 in The New York Times in the United States. In "The Next Economic Powerhouse? Poland”, he suggested that

of the more than 190 countries tracked by the International Monetary Fund, fewer than 40 count as wealthy or advanced economies. The rest are known as emerging nations, and many of them have been emerging forever. The last large country to make it into the advanced class was South Korea, 20 years ago. The next major nation likely to join that club could be Poland... a common thread is that all the nations have a per-capita income of at least around $\$ 15,000$... Poland's average income has risen to near $\$ 13,000$, from $\$ 2,300$, and it is now on pace to pass the $\$ 15,000$ mark by the turn of this decade. ${ }^{73}$

\footnotetext{
${ }^{71}$ Foy.

${ }^{72}$ Goraus and Inchauste.

${ }^{73} \mathrm{http}$ ///wgospodarce.pl/informacje/38233-new-york-times-polska-nowaekonomiczna-potega; see also https://www.nytimes.com/2017/07/05/opinion/
} 
He did not forget about the concerns among the governments of Western states and commentators of the Western press, who were afraid of the growth of populism after the success of PiS in the parliamentary election: "The concern was that it would derail growth by meddling in the private sector and trying to fulfill costly populist promises. ... So far these policies have not caused much harm.".74

Today, we already know that his predictions were correct. By the end of September 2017, for the first time in its history, Poland was not recognized among the emerging markets, but among the developed markets. The FTSE Russell index agency has considered us the first Central European state to join the 25 best developed countries, and as of September 2018 we will be recognized together with such countries as Germany, Japan, or the United States. ${ }^{75}$

Andrew Marr, BBC's political commentator, in his famous Sunday Times piece "Thank you, Poland, for lending us your young", praised the Polish immigrants:

If we sit down with a piece of paper and a pencil and try to work out the ideal source of migrants to Britain, I suspect that after analyzing all the percentages, historical dates, and economic equations, we would end up with the word Poland circled, underlined, and followed by three exclamation marks.

... Polish pilots fought in the Battle of England, and the Brits expressed their deepest respect for the Polish dissidents during the communist times and the Solidarity era. My generation knows many Polish writers and composers, including Czesław Miłosz, Wisława Szymborska, Zbigniew Herbert, and Witold Lutosławski, and Pope John Paul II was always treated as a world leader in the format of Nelson Mandela.... 99 percent of immigrants from Poland have a permanent job or are studying. Poles have opened more than 22,000 businesses in the British Isles. (...) We helped the Poles, offering them higher wages, and they helped us. While Vladimir Putin is flexing his muscles and we are trying to define our priorities in the process of leaving the European Union, we should ask ourselves who our good friend is. ${ }^{76}$

And here is a funny comment by Giles Coren in his "How to be a lazy Brit" piece, pre-announced a day earlier, in The Times centerfold: "The Poles coming to

\footnotetext{
poland-economy-trump-russia.html

${ }^{74}$ Op. cit.

${ }^{75}$ https://www.money.pl/gielda/wiadomosci/artykul/ftse-russell-polska-rynek-rozwiniety,122,0,2371450.html, https://www.gpw.pl/aktualnosc?cmn_id=10603, https:// www.gpw.pl/pub/GPW/files/PDF/2017_09_FTSE_Russell.pdf

${ }^{76}$ Marr.
} 
Britain work very hard. After a few years here, they start to mimic the Brits and become equally lazy."77

But there is only a minority of such comments. For the last eighteen months, the prevailing body of articles were one-sided pieces, with a black-and-white hypothesis, typically suggesting that Poland has problems respecting the rule of law or democratic values, and that it is "rolling down towards a Nazi-like dictatorship." They emphasized that Poland's present government had "symbolically half-masted the EU flag,"78 nevertheless declaring that they did "not intend to get Poland out of the European Union"79 and that they were "happy to take the EU money". ${ }^{80}$ There were suggestions that "other EU member states would be happy to see Poland outside the EU." ${ }^{81}$

\section{SUMMARY ${ }^{82}$}

Today, more than eighteen months after the October 2015 election in which PiS was the winner, we seem to have already passed the peak of this unhealthy interest in Poland. The activity of foreign correspondents seems to be declining in strength, so it is now possible to calm the emotions and slowly begin to summarize things. However, it is still not possible to authoritatively determine the causes of the negative press campaign about Poland, nor is it easy to estimate all its consequences.

Among the results, there is the change of Poland's image in the international scene, the incoherent and ambiguous perceptions of Poland among the European political elites, the new ratings of Poland by the international financial institutions (first a negative perspective was assigned, then there was another switch from negative to stable), and the continuously valid threat of sanctions for noncompliance with the rule of law (the threat of withdrawal or reduction of structural funds and the denial of Poland's voting rights in the European Council).

${ }^{77}$ Coren.

${ }^{78}$ Foy.

79 "Illiberalism lives."

${ }^{80}$ Foy.

81 "Illiberalism lives."

${ }^{82}$ This paper does not cover the topic exhaustively; rather, it should serve as a starting point for further discussion. Careful observation and analysis is still needed for the issues under consideration. 
It is certainly safe to conclude that, contrary to the ominous forecasts, 2016 was a good year for foreign investment in Poland: the value of investment grew by $74 \%$ over the preceding year. ${ }^{83}$ According to the fDi Intelligence report developed at the Financial Times analytical division, last year foreign businesses announced new investment in Poland worth USD 9.9 billion (equivalent to PLN 38 billion). ${ }^{84}$ Based on estimations, Poland is therefore ranked fifth in Europe, achieving a better bidding and investing position than many richer countries in Europe, such as Spain or Ireland. ${ }^{85}$ The positive opinion investors have about our economy is further supported by the publication of our credit rating by Moody, of 12 May 2017. Moody maintained Poland's credit rating at A2 and, importantly, changed its perspective again, this time from negative to stable. In this way, the negative forecasts from autumn have gotten better. The implication is that the agency does not see any threat of decreasing Poland's credit capacity.

The prospects for foreign trade are optimistic as well: the data of the Central Statistical Office (GUS) for 2016 demonstrate a 2.3\% growth in Polish exports (up to $€ 183.6 \mathrm{bn}$ ), a $0.9 \%$ rise in imports (up to $€ 178.9 \mathrm{bn}$ ), and an almost doubled turnover surplus (up to nearly €4.8 bn). ${ }^{86}$ During the visit of Chinese President Xi Jinping to Poland in June 2016, more than ten bilateral agreements were signed in areas such as banking and air traffic; Poland's role in the new Silk Road reconstruction project was strongly emphasized - it is intended as a road project linking China with Europe. Moreover, in September 2017, for the first time in its history, Poland was not recognized among the emerging markets, but among the developed markets. Next year, we are expected to join the group of the 25 most developed countries worldwide.

The number of tourists coming to Poland is increasing regularly, too. The Ministry of Sports and Tourism declared that the number of foreign tourists had broken the previous record in 2016. It increased by $4.5 \%$ over 2015, up to approx. 17.5 million (12.5 million in Krakow alone). ${ }^{87}$

${ }^{83}$ For a broader discussion of the topic, see Siemiończyk; http://www.tvp.info/30762 014/inwestorzy-cenia-polske-gospodarka-sie-rozpedza

${ }^{84}$ Op. cit.

${ }^{85}$ For a broader discussion of the topic, see "Zagraniczne firmy nie boją się rządu PIS."

${ }^{86}$ https://www.mr.gov.pl/strony/aktualnosci/handel-zagraniczny-polski-w-2016-r. 6615.htm

${ }^{87} \mathrm{http}: / /$ tvn24bis.pl/z-kraju,74/turystyka-w-2016-r-wiecej-turystow-z-zagranicy,71 
Furthermore, it appears from the quoted opinion polls and journalistic articles that the image of Poles as a nation is becoming more and more positive in the West. This image is built by hardworking, well-educated migrants who often study at universities in Western European countries and start working in highly specialized jobs afterwards. The 'unremarkable' image of the Polish state ("Polska bez twarzy"), so prominent in the opinion polls around 2010, has been replaced by an image of a state in good economic condition, but breaking the rules of democracy. Poland is a country with good economic and investment prospects (no longer an emerging market, but already a developed market), which is nonetheless experiencing certain political problems, is torn by internal conflicts, and governed by a Nazi-like dictatorship that has immobilized the Constitutional Tribunal and the free media, and which did not support its candidate for president of the European Union Council (the first member state to do so in the history of the EU). Even for an inattentive observer of international affairs, this conclusion is quite predictable, yet this is exactly the shape of Poland's contemporary perception on the European political scene.

Despite the numerous positive comments in the press or on TV about the two significant visits for the Poles (Donald Trump on July 6 and Kate and William Windsor on July 17, 2017, an event that uniquely promoted Poland's history, culture, and aspirations all over the world), there was definitely no breakthrough in the way Poland has been described since. After some brief delight with Poland as the "geographic heart of Europe,"88 "the spirit of Europe,"89 and "a model and symbol of hope for the survival and triumph of the Western civilization," ${ }^{\prime 90}$ and with the Polish people "fighting for independence in a valiant, courageous, and determined way," or money, they just wanted God,"92 the public opinion in Europe became interested in the matter of the reform of the Polish justice system. There began to ap-

${ }^{88}$ Donald Trump's speech at Plac Krasińskich in Warsaw, July 6, 2017, as quoted in https://www.wprost.pl/kraj/10063965/1/Komentarze-w-swiatowych-mediach-po-wizycieTrumpa-w- Warszawie-Polska-jako-przyklad.html

${ }^{89}$ Ibidem.

${ }^{90}$ Ibidem.

${ }^{91}$ Speech by Prince William Windsor at Łazienki Palace, Warsaw, 17 July 2017

${ }^{92}$ https://www.wprost.pl/kraj/10063965/1/Komentarze-w-swiatowych-mediach-powizycie-Trumpa-w- Warszawie-Polska-jako-przyklad.html 
pear mentions of a "dependent judiciary," ${ }^{\prime 3}$ the "effort to subjugate the legal system to a politician's control," ${ }^{94}$ and how "from the mountain resort of Zakopane in the south to the Hel peninsula in the north, tens of thousands of Poles took to the streets ... in protest against the ruling party's policy" [Translator's note: the italicized passage is completely different from the original quote from the source given in the reference; see https://www.economist.com/europe/2017/07/29/aveto-gives-the-rule-of-law-in-poland-a-reprieve]. ${ }^{95}$ After Andrzej Duda's veto on July 24, the following comment was published: "taking control over the judiciary in Poland was stopped for a moment, but the threat to the rule of law in Poland is far from over." [Translator's note: the initial passage in italics is completely different from the original quote from the source given in the reference; see: https:// www.economist.com/europe/2017/07/29/a-veto-gives-the-rule-of-law-in-poland-a-reprieve]. ${ }^{96}$ Not all the comments were so elegant. A Norwegian journalist's comment about president Duda's tweet reverberated strongly among Polish Internet users: "Kaczynski's dog became a man."

There is no way we can speak of any breakthrough in the negative narrative or of any change of style in what is written about Poland. Thus, the media reports should still be observed with proper attention. After all, "the image of a country is a certain kind of currency, which can be exchanged for other goods: political cooperation for the accomplishment of goals... incoming investors, export opportunities, interest among tourists, culture consumers.... ${ }^{98}$ It should be reiterated continuously that the consideration of Poland's image on the international scene is still an important task, not only for the political elites or decision-makers, but also for all informed citizens of our country.

93 "Dependent judiciary."

94 "Dependent judiciary."

95 "Objection sustained."

${ }^{96}$ Ibidem.

${ }^{97}$ https://wiadomosci.wp.pl/skandaliczne-slowa-norweskiego-dziennika-o-dudzielawina-komentarzy-6148287146247809a

${ }^{98}$ Olins, Laboratorium Badań Społecznych for the Ministry of Foreign Affairs 13. 


\section{REFERENCES}

\section{OPINION POLLS:}

BEST PLACE - Europejski Instytut Marketingu Miejsc [European Place Marketing Institute]. "Eye on Poland. Promocja i wizerunek Polski w oczach międzynarodowych ekspertów marketingu miejsc" [Eye on Poland: The promotion and the image of Poland among the international place marketing experts], January 2012.

European Commission. "How Europeans see themselves: Looking through the mirror with public opinion surveys," Luxembourg, 2001.

"Green-eyed continent." The Economist, 29 March 2016.

Instytut Spraw Publicznych [Institute of Public Affairs]. "Barometr Polska- Niemcy" [Poland-Germany Barometer], Autumn 2013.

Laboratorium Badań Społecznych for the Ministry of Foreign Affairs. "Określenie wizerunku, który Polska powinna promować za granicq" [Determination of the image which Poland should promote abroad], Warsaw, November 2013.

Pew Research Center. Stereotyping in Europe, 2012 and 2013.

Standard Eurobarometer no. 86, Europeans' opinion of the EU's priorities, November 2016.

\section{ELECTRONIC SOURCES:}

http://www.bankier.pl/wiadomosc/PKB-na-osobe-w-Polsce-goni-srednia-UE-Mocnywzrost-do-2018-roku-7255686.html

http://www.cer.eu/sites/default/files/publications/attachments/pdf/2014/bal_comp_

ib_eu_enlargement_july2014-9463.pdf

http://www.doingbusiness.org/reports/global-reports/doing-business-2017

www.eurostat.com

https://www.gpw.pl/aktualnosc?cmn_id=10603

https://www.gpw.pl/pub/GPW/files/PDF/2017_09_FTSE_Russell.pdf

https://www.money.pl/gielda/wiadomosci/artykul/ftse-russell-polska-rynek-rozwinie-

ty,122,0,2371450.html

https://www.mr.gov.pl/strony/aktualnosci/handel-zagraniczny-polski-w-2016-r.

https://www.nytimes.com/2017/07/05/opinion/poland-economy-trump-russia.html

https://www.obserwatorfinansowy.pl/tematyka/makroekonomia/wymiana-handlowa-

miedzy-polska-a-niemcami-na-rekordowym-poziomie

http://www.polandgoglobal.pl

http://www.pot.gov.pl/nowosci/l/wiadomosci/wiadomosci-z-pot/nagrody-best-intravel-2016-rozdane- polska-w-czolowce-swiatowych-destynacji-turystycznych https://richardbrenneman.wordpress.com/2013/05/14/chart-of-the-day-howeuropeans-see-each-other

http://tvn24bis.pl/z-kraju,74/turystyka-w-2016-r-wiecej-turystow-z-zagranicy,716615. htm 
http://www.tvp.info/30762014/inwestorzy-cenia-polske-gospodarka-sie-rozpedza https://wiadomosci.wp.pl/skandaliczne-slowa-norweskiego-dziennika-o-dudzie-lawina-komentarzy-6148287146247809a

http://wgospodarce.pl/informacje/38233-new-york-times-polska-nowa-ekonomicznapotega

https://www.wprost.pl/kraj/10063965/1/Komentarze-w-swiatowych-mediach-powizycie-Trumpa-w- Warszawie-Polska-jako-przyklad.html

http://wyborcza.biz/biznes/1,100896,19329021,polska-w-pierwszej-dwudziestce-najchetniej-odwiedzanych-krajow.html

\section{POLISH PRESS:}

Bachman, K. “Wejście po przejściach” [Rough Accession]. Polityka, 20 July 2002.

Bielecki, J., and Stankiewicz, A. "Witajcie w Unii, jeśli musicie" [Welcome to the EU if you have to]. Rzeczpospolita, 26 April 2002.

Dawidowski, A. “Żadnych złudzeń” [No illusions]. Unia i Polska, 23 October 2000.

Dessler, J. "Komisja Europejska o przywarach Polaków" [The European Commission on the bad qualities of the Poles]. PAP/Polish Press Agency, July 2001.

Grzeszak, A. "Poland- gdzie to jest? Przymiarka do marki" [Poland - where is it? Fitting to measure]. Polityka, 25 May 2002.

Saryusz Wolski, J. "Ekonomiczny apartheid" [Economic Apartheid]. Die Welt, 28 November 2002.

Siemiończyk, G. "Inwestorzy cenią Polskę" [Investors value Poland]. Rzeczpospolita, 15 May 2017.

Skotnicka-Illasiewicz, E. "Swojska kultura lękliwości. O sposobach postrzegania UE przez Polaków i unitów" [The familiar culture of fearfulness: On the perceptions of the EU among the Poles and EU citizens]. Unia i Polska, 3 September 2001.

Smoczyński, W. "Polska - kraj bez twarzy" [Poland - A country without a face]. Polityka, 30 June 2009.

Swieżewska, Dominika. "Jak postrzegają nas Brytyjczycy, czyli wizerunek Polaka na Wyspach" [How the Brits see us, or the image of a Pole in the UK]. http://polemi.co.uk/ lajt/artykuly/wizerunek-polakow-w- wielkiej-brytanii-5511; www.kobietawuk.info.

"UE- Polak to pazerny fatalista" [EU - A Pole is a greedy fatalist]. Wirtualna Polska, 25 July 2001.

"Zagraniczne firmy nie boją się rządu PIS" [Foreign companies not afraid of the PIS government]. Rzeczpospolita, 15 May 2017.

\section{FOREIGN PRESS:}

Blankley, T. "France blackmails Poland.” The Washington Times, 19 February 2002.

Buras, P. “Driving Poland apart." The New York Times, 23 December 2015.

Coren, Giles. "How to be a lazy Brit: The easy way to become a great British builder." The Times, 27 May 2017. 
"Courting disaster." The Economist, 2 January 2016.

"Dependent judiciary: Populism in Poland." The Economist, 22 July 2017.

Diehl, J. "Poland's disturbing tilt to the right." The Washington Post, 29 November 2015.

Dietrich, A. "Auf dem Weg in die nationalkonservative Diktatur". Die Welt, 23 December 2015, as quoted in http://www.pap.pl/aktualnosci/news,449879,niemieckie-media-o- polsce-polskie-wladze-przekroczyly-rubikon.html.

"Europe's new headache: The new government in Poland has made an awful start." The Economist, 5 December 2015, as quoted in http://wiadomosci.gazeta.pl/ wiadomosci/1,114871,19291093,jak-the-economist-widzi-dzis- $\quad$ polske-6-naprawde-gorzkich-cytatow.html.

Foy, H. "Barbed rhetoric." Financial Times, 27 November 2015.

"Green-eyed continent." The Economist 29 March 2016.

Hanley, S., and Dawson, J. "Poland was never as democratic as it looked." Foreign Policy, 3 January 2017.

"Illiberalism lives." The Economist, 29 April 2017.

Marr, A. "Thank you, Poland, for lending us your young - a migration that really works." The Sunday Times, 28 August 2016, as quoted in http://demotywatory.pl/4685519/ Brytyjski-publicysta-BBC-dziekuje-Polsce-Dziekuje-ci.

"Objection sustained: Illiberalism in Poland." The Economist, 29 July 2017.

"Poland's Tragic Turn." The New York Times, 21 December 2016.

Santoso, A. "Greek Think They're the Hardest Working People in Europe." The Economist, 4 June 2012.

Sharma, Ruchir. "The Next Economic Powerhouse? Poland." The New York Times, 5 July 2017.

Staniszkis, Jadwiga. Interview in Die Welt, "Kaczynski hat keine Empathie für sein Volk," 19 January 2016.

"The return of the awkward squad: Two weeks in, Poland's new government is making Europe nervous." The Economist, 5 December 2015.

Ulrich, S. "Kaczyński zerstört den polnischen Rechtsstaat." Sueddeutsche Zeitung, 23 December 2015, as quoted in http://www.pap.pl/aktualnosci/ news,449879,niemieckie-media-o-pol-sce-polskie-wladze-przekroczyly-rubikon. html

Veser, R. "Polen und Deutschland: ziemlich beste Freunde." Frankfurter Allgemeine Zeitung, 16 June 2016.

Zakaria, F., CNN o Polsce [CNN on Poland]. CNN, 6 December 2015, as quoted in http:// wyborcza.pl/1,75399,19304320,cnn-o-polsce-wydarzenia-przybra-ly-bardzo-zlyobrot.html.

Zakaria, F. “Global Public Square.” CNN o Polsce [CNN on Poland]. CNN, 6 December 2016, as quoted in https://oko.press/demokracja-krucha-spojrzcie-polske-rosje-turcjeekspert-cnn-zniecheca-trumpa. 


\section{LITERATURE:}

Advisory Council on International Affairs. "The EU Capacity for Further Enlargement", no. 71, 2010. http://aiv-advies.nl/download/1b2da592-0f83-4791-b83f-fe822471ff84. pdfs.

Balzer, A. "Just A Platonic Love? Poland and the EU Enlargement." Poland and the Czech Republic: Advocates of the EU Enlargement?, Demos EUROPA Center for European Strategy, Warsaw, 2010.

Bond, I. EU Enlargement, Center for European Reform. www.cer.org.uk.

Fomina, J., and Frelak, J. Wizerunek Polski i Polaków w Wielkiej Brytanii [The Image of Poland and the Polish People in the United Kingdom], ISP, 2011.

Goraus, K., and Inchauste, G. The Distributional Impact of Taxes and Transfers in Poland, World Bank Report, August 2016.

Holzer, J. "Polacy i Niemcy- wzajemne postrzeganie" [Poles and Germans: Their Mutual Perception]. Kultura i społeczeństwo, vol. XLI, ISP PAN, 1997.

Kolarska-Bobińska, L. Odmienność oswajana. Obraz Polski w krajach Unii Europejskiej [Tamed Diversity: The Image of Poland in the European Union Member States], Instytut Spraw Publicznych [Institute of Public Affairs], Warsaw, 2003.

Koves, A. Central and Eastern European Economies in Transition: The International Dimension, Westview Press, San Francisco, 1992.

Martinez Reyes, V. Reguły gry, czyli o negocjacjach akcesyjnych i łączeniu się Europy [Rules of the Game, or About the Accession Negotiations and the European Integration], Naukowe Scholar, Warsaw, 2000.

Niklewicz, K. Przewodnictwo Polski w Radzie Unii Europejskiej [Poland's Presidency in the Council of the European Union], 2013.

Olins, W. Tożsamość rynkowa. Atrybut konkurencyjnego Państwa [Market Identity: An Attribute of a Competitive State], Instytut Marki Polskiej, Warsaw, 2001.

Płonka, B. Polityka Unii Europejskiej wobec krajów Europy Środkowej [European Union Policy Toward Central European Countries], UJ, Krakow, 2003.

Sedelmeier, U. Europe after the Eastern Enlargement of the European Union: 2004-2014, Heinrich Boell Stiftung, 2014.

Walkiewicz, W. Polska na drodze do Unii Europejskiej. Aspekty negocjacyjne i dostosowawcze [Poland on its Path to the European Union: Negotiation and Adaptation Aspects], Rzeszów, 2002.

Warchala, M., editor. Wizerunek Polski w prasie krajów Unii Europejskiej [The Image of Poland in the Press of the EU Member States], Instytut Spraw Publicznych [Institute of Public Affairs], Warsaw, 2002.

Wnuk-Lipiński, E. “Członkostwo Polski w Unii Europejskiej - pierwsze problemy i kryzysy społeczne w Polsce" [Poland's Membership in the European Union: First Social Issues and Crises in Poland." Polska w Unii Europejskiej. Poczq̨tkowe problemy i kryzysy? [Poland in the European Union: First Issues and Crises?], PISM, Warsaw, 2002. 


\section{About the autor}

Karolina Świrska-Czałbowska, Ph.D. is a lecturer at Cardinal Stefan Wyszyński University. She has published in such periodicals as "Polis - pismo o sztuce życia publicznego", by the Institute of Political Studies, Polish Academy of Sciences (ISP PAN); "Studia europejskie", a quarterly of the Centre for Europe, University of Warsaw; "Problemy zarządzania"; "Studia i materiały"; the Institute of Economic Studies, Polish Academy of Sciences Report; Magazyn Niezależnych Publicystów "Unia i Polska"; "Tygodnik Powszechny"; and "Arcana". Her research interests cover the image of Poland and the Poles abroad, the issue of building a national brand, national branding and national market identity, and the promotion of Poland worldwide in the cultural, political, and economic aspects. Contact: kswirska@wp.pl 